\title{
The Credit Crunch: Neo-Liberalism, Financialisation and the Gekkoisation of Society
}

\author{
by John D. Bone \\ University of Aberdeen
}

Sociological Research Online, Volume 14, Issue 2,

$<$ http://uww. socresonline.org.uk/14/2/11.html>

doi:10.5153/sro. 1928

Received: 11 May 2009 Accepted: 26 May 2009 Published: 30 May 2009

\begin{abstract}
This paper offers a broad overview and analysis of some of the main causes and consequences of the current economic crisis. While attempting to flag up some of the key continuities between the conditions contributing to the current crisis and those that produced the 'great crash' of 1929, it is argued that the 'credit crunch' must be understood in broad historical context. Specifically, it is suggested that the turn to neo-liberal economics in the late 1970's, principally in the UK and US, restored many of the structures and socio-economic characteristics that were prevalent in the 1920's, inevitably producing a highly similar outcome. Overall, it is argued that the (re)financialisation of the economy, the deregulation of markets, together with the cultivation of a culture of rampant individualism and acquisition, pervading the markets and wider society, have coalesced to sow the seeds of reckless profit seeking that have led to the current crisis. Moreover, given that latter, it is suggested that the current upheaval is as much a reflection of social and cultural decay as it is a failure of economic governance.
\end{abstract}

\section{Keywords: 'Credit Crunch', Neo-Liberalism, Financialisation, Housing Bubble, the 'Great Crash', 'Gekkoisation'}

\section{Introduction}

\begin{abstract}
...Practices of the unscrupulous money changers stand indicted in the court of public opinion, rejected by the hearts and minds of men. True, they have tried, but their efforts have been cast in the pattern of an outworn tradition. Faced by failure of credit, they have proposed only the lending of more money. Stripped of the lure of profit by which to induce our people to follow their false leadership, they have resorted to exhortations, pleading tearfully for restored conditions. They know only the rules of a generation of self-seekers. They have no vision, and when there is no vision the people perish. The money changers have fled their high seats in the temple of our civilization. We may now restore that temple to the ancient truths. The measure of the restoration lies in the extent to which we apply social values more noble than mere monetary profit.

(President Franklin D. Roosevelt, Inaugural Address, March 4th 1933)
\end{abstract}

1.1 Over the last year, a great deal of the more serious output from the world's media has been dominated by discussion of the 'credit crunch', its causes and its potential consequences. The broad consensus of this debate has been that the world's bankers, and associated players in the financial sector, had overreached themselves in terms of engaging in risky financial dealings, and lending far too much money for people to overindulge in consumption and, in particular, investment in property.

1.2 It appears clear, however, that the current crisis represents more than merely a cyclical outbreak - albeit a serious one - of 'irrational exuberance' amongst the financial community (Shiller, 2000). Rather, fundamental changes to the structure of the economy, the regulatory framework in which contemporary business has been conducted and, critically, the manner in which the culture of contemporary capitalism has evolved and pervaded the wider culture over the last three decades, in various ways that are briefly discussed below, can be seen to have coalesced to produced conditions that inevitably lend themselves towards increasing instability and crises, such as that currently being experienced.

1.3 Supporting this view, the evident parallels in terms of economic policy, financial management, organisation, culture and practice that led to the crash of 1929 indicate that the current crisis is evidence of 
a deeper systemic problem, that should have been relatively easy to foresee and which has produced a crisis not just for the economy but for society as a whole (Galbraith, 1929; Krugman, 2008). Moreover, underlining the broad consistencies between the 1929 crisis and the present, the sentiments expressed in the opening quotation, as it assigns responsibility for the 'Great Crash' and subsequent depression, aside from its somewhat arcane rhetorical style, might clearly resonate with many who are familiar with the circumstances of the current crisis.

\section{The Neo-liberal Dawn: The Beginning of the Shift}

2.1 For many commentators the seeds of the 'credit crunch' were sown with the turn to neo-liberalism, and the concomitant re-ordering of economy and society that commenced, principally in the US and UK, in the late 1970's and early 1980's. The transition from a 'mixed' to a market economy, however, has been so extensively discussed that it is both unnecessary, and impossible, to do it justice in such a short piece. However, as is argued below, undoubtedly one of the most crucial feature of neo-liberal policy, at least in terms of its role in creating the conditions that have led to the current crisis, was the (re)turn to finance as a key driver of the economy amid the decline of the manufacturing that was a hallmark of this era, and the manner in which the culture of a more selfish, predatory and licentious form of rentier capitalism associated with this sector has permeated society as a whole (Hutton, 1995).

\section{The Financial 'Turn'}

3.1 The expansion and deregulation of finance at all levels - from investment banking to consumer finance was an integral feature of neo-liberal policy in both the UK and US for a number of reasons, both pragmatic and ideological. From a pragmatic standpoint the economic and employment vacuum opening up in the wake of a declining manufacturing sector, contracting under pressure from increasing global competition, had to be filled by something else, and financial and other services began to be viewed as the obvious alternative (Brenner, 2005). From an ideological perspective, however, with the turning away from Keynesianism, most particularly within the 'Anglo Saxon' nations who advanced the 'new' economics, the deregulation of finance seemed a fairly obvious step, consistent with the neo-liberal credo that artificial constraints on market activity merely generate imbalances while restricting dynamism and growth (Hutton, 1995). What emerged from this deregulatory drive was an extended number of financial institutions that were now free to engage and compete across a broad range of previously restricted and specialised financial activities, both domestically and globally (Hutton, 1995; Elliott \& Atkinson, 2008).

\section{Then and Now}

...the common denominator of all speculative episodes is the belief of participants that they can become rich without work (Galbraith, 1961: 10).

4.1 In broader perspective, the unshackling of the financial sector marked a reversal of the policies that had regulated and contained its activities throughout the post-war era, given that the crash of ' 29 and succeeding depression had largely been attributed to the reckless and avaricious activities of unrestricted 'big finance' and the 'laissez-faire' form of economic management that had been the received wisdom until this period (Galbraith, 1961).

4.2 The 1920's had seen a huge credit boom, an expansion of debt-fuelled consumption, rising inequality and a real estate boom and bust, in addition to record trading volumes reflecting the now infamous speculative frenzy that overtook the stock markets, and which saw increasing numbers of the public buying up stocks, often on credit, in the hope of emulating the wealthy financiers of the times and becoming effortlessly wealthy. While public participation during the recent 'bubble', as is discussed below, largely involved speculation in property rather than shares, nonetheless, the parallels with the 1920's are striking. This is perhaps understandable, given that the deregulation of finance and the thinking that has driven economic policy since the late 1970's, in a number of important respects, echoed the economic policies, practices and culture that were prevalent in the '20's (Krugman, 2008).

4.3 By the early 1980's, the financial sectors in the US and UK, whose presumed economic role was to oil the wheels of the (real) economy - facilitating transactions between investors/savers and borrowers, moving resources and credit to where they could be employed most productively and efficiently and, crucially, managing financial risk - once more, began to take on a life of its own, becoming the master rather than the servant of real economic activity (Elliott \& Atkinson, 2008; Orhangazi, 2008). Overall, as the real economy stagnated or contracted this was masked to some extent by the growth in the financial sector and the expansion of credit, fuelling both its own activities, a sequence of speculative bubbles, and the debt fuelled consumption led economies that it fostered (Hutton, 1995)

\section{Booty Capitalism \& the 'Gekkoisation' of Society}


5.1 The growing power and reach of the financial sector - and the pace with which new technologies now allowed capital to be shifted across an increasingly globalised economy - had a profound impact on both economy and society. 'Big finance' placed increasing pressures on companies in the 'real' economy to deliver, as capital began to demand higher and higher returns on investment over ever shorter time periods (Hutton, 1995). With a constant eye on quarterly profits and shareholder value, and wary of hostile takeover from predatory financiers, companies were driven to constantly squeeze costs, while the remuneration of corporate CEO's was linked to short term profitability and share price such that their personal financial interests became broadly aligned with those of the markets. The risks of trading in this environment, however, were largely shifted towards employees in the form of increasingly casualised, insecure and, for many, sporadic employment or idleness, supplanting the secure and predictable employment arrangements of the post-war era (Michie and Sheehan, 2003).

5.2 The general public were 'compensated' for increasing job insecurity - and, in many cases, contracting or stagnating incomes - by an increasingly plentiful flow of consumer credit, and greater access to financial products, made available by the expanded retail arm of the financial sector. For some, easier access to credit merely provided the opportunity to assuage the travails and insecurities of the new economy by engaging in some 'retail therapy'. Many others, however, began in their own small way to emulate the moguls of finance by buying shares and unit trusts, or by borrowing to invest and speculate in residential property and other forms of competitive and, often, exploitative wheeling and dealing (Hutton, 1995).

5.3 Moreover, engagement in such activities appeared to provide evidence, echoing Marx, that the financialisation and marketisation of the economy were being matched by a parallel shift in consciousness, at least amongst a significant sector of the public. A 'new' entrepreneurial culture, together with the notion that burgeoning wealth at the top would 'trickle down' throughout society, was assiduously promoted by the political establishment and their supporters in an increasingly partisan media. While growing inequalities offered little evidence of a wider extension of wealth, what did appear to 'trickle down' was some aspect of the mindset and culture of the financial elite, an appetite for acquisition, luxury and status amongst those who began to see the appeal of swift and relatively effortless wealth generation as a preferable alternative to insecure employment (Rapley, 2004).

5.4 An increasing emphasis on high short term gains at all levels, and a concomitant notion that the ends justified the means in the 'hard nosed' pursuit of profit, appeared to mark a sea change in the very nature of contemporary capitalism. In certain respects it could be suggested that the characteristics of the 'new' economy appeared consistent with Weber's description of 'booty' or 'adventure' capitalism, an anachronistic and marginal form that was meant to have been supplanted by rational capitalism characterised by long term planning, stable returns and honest dealing - in the modern era (Weber, 1930).

5.5 Given its foundations, this new economy was also often capricious and unstable, producing great rewards for some and substantial losses for others, both in the volatile financial markets and further down the line in the property and associated markets that, as is discussed in more detail below, experienced a sequence of booms and busts from the 1980's until the present. This was the era of the 'yuppie' and 'loadsamoney' where the winners flaunted their gains, regardless of how they were achieved, while the substantial number of losers assumed the culpability for circumstances that were often beyond their control.

5.6 The rationalisation for the more questionable practices and harsher aspects of this increasingly unequal and insecure society - and for activities where profits where obtained through reckless speculation, through assaults on others' livelihoods and through taking advantage of others and abusing their trust - was to cite what amounted to a dusted down credo of Social Darwinism as the legitimating principle (John D. Bone, ). Thus, the received wisdom of this period was that the entrepreneurial world was no place for the idle or the weak, that the sovereignty of the market - and thus the distribution of reward and loss - was unchallengeable, while the latter were a reflection of individual effort and ability rather than circumstance. Echoing the credo espoused by the new financial elite, winning and losing were dependent on talent and effort as opposed to luck and circumstance.

The idea that we're nothing more than selfish animals is an attractive philosophy to a person pulling down a few million dollars a year. It is a philosophy that negates guilt. The guilty feeling a normal person gets while visiting a Third World country is the same feeling a senior investment banker gets when they see a working class neighborhood in Birmingham or Philadelphia. When your paycheck could cover the salaries of a few hundred nurses or teachers, you need some explanation for why that's okay. The only one that really works is that life is a pure meritocracy. That whether rich or poor, we're all getting what we deserve. (Meyer, The Independent , 27th April 2009).

5.7 Overall, with the consolidation of neo-liberal thinking, a fundamentalist version of Adam Smith's 'invisible 
hand' was grasped by a significant sector of the population, in a form stripped of both nuance and moral context to become the mantra of the neo-liberal age; 'greed is good', 'lunch is for wimps', 'look after number one', 'winner takes all' and markets left to themselves produce the best outcome - eventually. Such sentiments, and the attitude and ideology that informed them, as the sub-heading to this piece suggests, appeared to be personified in the iconic figure of the unashamedly amoral and predatory financier Gordon Gekko, as portrayed by Michael Douglas in Oliver Stone's 1987 film 'Wall Street'. Moreover, it can be argued that the lionisation of such characters and their credo in the mass media since the 1980's - both fictional figures and their real world counterparts - has provided the role models that have nurtured an exploitative and uncompassionate attitude to others in the avaricious pursuit of personal gain, within both the business community and wider society; a mindset that has propelled us towards what is simultaneously a social, cultural and moral as well as purely economic crisis.

\section{Hitting the Buffers}

6.1 The warning signs that all was not well with the new socio-economic order had appeared evident to a range of informed observers since the 1980's, not least, as noted above, due to the parallels between current circumstances and those that had prevailed until the post war era (Galbraith, 1961; Krugman, 2008).

6.2 In social terms, there is little doubt that this was, for many, a much harsher and more fearful society than that of the post war period. However, even where this was conceded, it was suggested that the economic efficiency of the market society outweighed its social deficits and that, in any case, the globalisation of the economy rendered alternatives impractical. As is widely acknowledged, this was a standpoint largely accepted across the mainstream political spectrum, at least in the Anglo Saxon nations.

6.3 With respect to the economy, the period between the early 1980's and the current crisis, in addition to the expansion of the global economy, was marked by two interrelated phenomena; ever further expansion and deregulation of finance and credit, and a sequence of stock market and real estate booms and busts of increasing severity (Stiglitz, 2003). Economies such as the US and UK, experiencing greater global competition in manufactures from the rising industrial states of India and China, became ever more reliant on their financial sectors, consumption and expanding credit to maintain economic growth. The recognition of this, together with the general political acceptance of the principles of self regulating markets, led to ever more light regulation of the financial sector.

6.4 Free from any real constraints or oversight the financial sector stepped up its activities in doing deals, trading, engaging in takeovers and mergers, and selling an expanding range of loans, securities and other financial products to investors and the general public. While there were very good grounds for drawing a connection between the expansion of finance and credit throughout the 1980's and '90's with the numerous periodic busts that arose in property and stock markets, the latter were largely regarded as mere cyclical events, temporary blips on the road to greater growth, rather than as indicators of a serious systemic problem. Moreover, the solution to these periodic mini-crises was the advancing of further credit to get the economy moving again, fuelling further asset bubbles (Stiglitz, 2003). Thus, the busts that followed speculative booms were treated by the engineering of further booms. However, some economic commentators began to recognise that the economy itself appeared to be becoming, essentially, a large speculative 'Ponzi Scheme' where wealth essentially generated by non-productive asset appreciation on a number of fronts was being supported by ever expanding debt. Moreover, rather than assisting what remained of the 'real' economy it appeared that the financial sector was becoming a destabilising influence, more engaged in furthering its own narrow financial interests than those of the shareholders and savers and the needs of the wider economy and society it was intended to serve. (Stiglitz, 2003; Elliott and Atkinson, 2008)

\section{The 'Croupier's Take', Bonuses and Risk}

7.1 Between the inflated share linked salaries and bonuses paid to CEO's and the rising commissions, fees and bonuses accruing to traders and fund managers - as the latter engaged in more trading, selling of new 'financial products' and merger activity, much of which appeared to have little function beyond the securing of fees and commissions - the amount of investors money ending up in the hands of financial managers and intermediaries (the so-called 'croupiers take) rapidly increased, providing the motivation for further activity for its own sake (Ford, 2008). In addition, the remuneration structure of the financial sector and the senior levels of large corporations provided a strong motivation for engaging in risky and short sighted activities. Thus, where the short term benefits accruing from highly risky business activity were large enough to be potentially life changing, or to allow a highly comfortable retirement should things go wrong, and as there was no provision for a 'clawback' of earnings once they had been secured, there was little incentive for caution. The demands of shareholders also entailed that any intermediary or financial institution that failed to follow the pack and deliver high returns would likely suffer the penalty. Moreover, the financial sector had learned from previous busts that, if things went wrong, central banks would step in with 
cheap money to put things right, while all of these factors raised the potential for 'moral hazard', where financial operatives, individually and collectively, began to assume that they would not be held accountable for their failings (Elliott and Atkinson, 2008).

7.2 The effect of these arrangements was that market participants had an overwhelming incentive to grab any potentially lucrative opportunity, even where they might be aware that the activities they were engaging in were risky and unwise. In the infamous words of Citigroup CEO Chuck Prince, 'as long as the music is playing you've got to get up and dance' (Ford, 2008:25).

7.3 While a range of market activities contributed to the financial crisis in some measure, including risky leveraged investment in stocks, as we now know it was the impact of financial sector activity and 'innovation' linked to residential property markets that, driven on by the culture of acquisition at all levels, led directly to the housing boom and bust whose effects continue to reverberate throughout the global financial system.

\section{Derivatives, Risk, Securitisation and Toxic Assets}

8.1 Ever eager to exploit potential new sources of potential profits, as suggested above, since deregulation the financial sector has extended the range of products, in addition to stocks and shares, which it offers to investors and other financial institutions. Crucially, in terms of the current crisis, this included the offering of a broad range of derivatives; financial instruments whose value is linked in various ways to real assets.

While financial derivatives are often highly complex, to such an extent that it is impossible to provide more than a cursory description here, their basic nature and function, however, is that they are designed to pay out to investors in the event of changes in the value of assets, currencies or commodities. In essence, they are regularly employed as 'side bets' where, for example, an investor exposed to oil stocks might buy a derivative contract that pays out if the price of oil goes below a certain level, thus mitigating risk.

8.2 However, paradoxically, one effect of a massive expansion of derivative contracts over the last decade was that they could also have the unintended consequence of increasing risk exponentially within financial markets. This marked disjuncture between the theoretical and actual operation of derivates, once more, could be seen to stem directly from finance's risk-taking and exploitative culture.

8.3 Part of the growth in derivatives involved increasingly risky 'bets' on a range of financial eventualities, with such derivative contracts themselves being speculatively traded with borrowed money. In a very basic sense there was an exponential growth in notionally highly valued 'betting slips' that became part of the asset portfolios of investors and financial institutions around the globe. The risk associated with these financial products was, perhaps, most dramatically expressed by veteran market guru Warren Buffett who referred to them as 'financial weapons of mass destruction'.

8.4 The now most notorious derivate contracts, given their central role in the current crisis, are MBS's (mortgaged backed securities), CDO's (collateralised debt obligations) and CDS's (credit default swaps). These contracts played a particular role in providing expanded finance to housing markets and were, thus, an integral part of the financial chain that linked the financial markets to 'Main Street' and fuelled the housing bubble. MBS's and CDO's were intended to extend credit and reduce the risk of expanded lending by financial institutions in a highly competitive mortgage market, by allowing loans to be parcelled up in tranches of varying risk and sold on to investors, who would pay up front to receive a relatively high rate of return as the mortgages were paid off. This process of securitisation, allowed lenders to sell on their mortgages, providing funds for further lending, rather than being restricted to lending linked to their own capital reserves. To ensure against the risk of holding these parcels of loans, investors and financial institutions who bought these products could also purchase a CDS; essentially an insurance contract that would pay out in the event of default.

8.5 In theory, all of this made sense. By parcelling up mortgages and selling them on lenders could access more funds providing opportunities for home ownership to a wider range of people, while investors could gain a steady income stream from an asset where the pooling of loans reduced the overall risk of the investment - i.e. it was considered that a few carefully calculated defaults would have little impact on the investment as a whole. However, the drive for commissions and fees 'deriving' from CDO's entailed that they did not operate quite as imagined. In short, as lenders could sell on their loans, with defaults becoming the end investors' problem, the underwriting of loans became of much less concern than their volume, as their was a steady stream of investors willing to purchase these lucrative, 'low risk' products. Moreover, the financial intermediaries in the City and Wall St were able to earn large commissions by packaging and selling increasing numbers of these products, even where the underlying loans were risky, quite simply as investors (and the regulatory authorities) did not understand them, and thus merely assumed that the risk profile on these products was as advised by the sellers and the financial sector agencies charged with rating that risk, who also had a financial interest in giving them a clean bill of health (Elliott \& Atkinson, 
8.6 This process of the financial sector selling complex and opaque contracts to unwitting investors, where at worst the purveyors had sound knowledge of the risks attached, encapsulated the 'hucksterism' that was consistent with the predatory and exploitative psychology of the market society, while echoing many of the sharp practices of Wall Street in the lead up to 1929.

8.7 Similarly with CDS's, many of these insurance contracts appeared to be little more than speculative bets that the housing market would continue to rise, that defaults would be few and, thus, they were often sold with the view that there would be little chance of having to pay out - as many of the institutions issuing these would not be able to meet their contractual obligations in a significant downturn.

\section{'Main Street' Speculators}

9.1 At 'ground level', as we now know, the rapid expansion and vigorous marketing of cheap and loosely underwritten mortgage finance provided by securitisation allowed for a rapid rise in house prices which, in turn, generated a speculative asset bubble of its own. Many more people were actively encouraged to access the 'property ladder' by lenders and a range of brokers and minor intermediaries, in the knowledge that there appeared to be little limit to the finance available to fund these loans, or little restriction on who would be deemed a suitable applicant (Elliott and Atkinson, 2008).

9.2 Importantly, however, in addition to owner occupation, the desire to expand the market also saw the introduction of mortgage products designed specifically for 'amateur' residential property investment. Property speculation began to be seen as a route to easy money in a number of countries, and particularly the US and UK, over the last decade. In the UK this trend was supported by government legislation that reduced tenancy rights while offering new tax concessions for property investors. Overall, property investment became a much more accessible, liquid and lucrative asset class than had once been the case. The upshot was that many amateur landlords/investors entered the housing market - some intent on long term 'pension' investment while others were involved in more direct short term speculation in a rising market, taking out a string of highly geared mortgages to build up a portfolio of properties. This resulted in what was essentially a battle of attrition between those seeking homes to live in and those seeking quick and easy profits, as the activities of many investors led to the pricing out of the market of potential owner occupiers, many of whom would then have little option but to become insecure tenants funding the investments of their market competitors (McWhirter, The Herald $16^{\text {th }}$ July, 2007).

9.3 As housing markets rose higher and higher, fuelled by the combination of increased, lax lending and speculation in property, The Economist $\left(16^{\text {th }}\right.$ June, 2005) suggested that this was becoming the 'biggest bubble in history'. Thus, urged on by a legion of estate agents, property pundits and an expanding media genre devoted to housing, the general public became obsessed with property and the potential wealth it might deliver.

9.4 Despite such warnings the property bubble ran on, with many economists, and in particular property and financial industry spokespeople, hailing the price rises as being due to 'market fundamentals'; evidence of growing wealth and prosperity, and a signal to non-owners and increasingly anxious and marginalised first time buyers that they had better act quickly or face the prospect of being priced out indefinitely. Governments and central banks were also unwilling to intervene, given that the expansion of housing wealth was now the key driver of consumption and the economy as a whole, the foundation of the financial pyramid, and a key barometer of electoral success. Once more, the parallels with the height of the stock bubble of 1929 were remarkable (Galbraith, 1961).

\section{The Fallout}

10.1 Inevitably, as the housing market and house prices rose to dizzy heights, some of the more risky mortgages began to default, and in far greater numbers than had been calculated by financial institutions and rating agencies, leading to a dash away from these assets amid a rising concern as to their real value. The issuance of new mortgage securities halted abruptly, while banks and other financial institutions that now held large quantities of these derivatives on their books began to question their own and each others potential exposure to these 'assets' and, thus, their solvency. Moreover, in addition to concerns over the value of pooled mortgage assets there was also grave concern re the ability to fund the derivative contracts intended to deal with such an eventually, to the extent that a call on these contracts might lead to default by holding institutions. As some major names in the financial sector, such as Bear Sterns and Lehman Brothers, began to go to the wall under the weight of these assets that were now becoming liabilities, highly valued stock markets tumbled around the world while governments faced the prospect that a mass insolvency, or a loss of confidence based on the fear of such an eventuality, such as that experienced at Northern Rock, might bring down the financial system as a whole. 
10.2 As has dominated the headlines over the last year, as market confidence collapsed new lending to both business and the public began to contract, while increasingly risk averse financial institutions refused to lend to each other. Overall, an economic system that, from top to bottom, had been built on risky speculative investment and a seemingly endless supply of cheap credit was now starved of oxygen, as the realities of over valued assets and over indebtedness began to become apparent. What it has left in its wake is an economic mess of historical proportions that may take many years to put right.

10.3 At present, ironically, the solution to this crisis is even more credit, in a seeming effort to patch up the system in its current form. This, as suggested above, has been adopted as the default solution to economic busts throughout the neoliberal era. However, as is now clear, the scale of the crisis is now stretching the budgets of central banks and governments to their limit.

10.4 The irony of this situation has been compounded by the fact, in addition to those who have left for wellheeled retirement, the remaining 'free marketers', who had for so long vigorously opposed and scorned any government involvement in the economy or any interference with their activities, have been the most vocal in calling for state intervention to rescue the economy, their industry and, hence, their incomes. The real casualties from this crisis, however, come further down the pecking order, and it is their incomes that will inevitably be called upon to foot the bill and their security that will be damaged over the longer term.

10.5 It is clear that the contraction of credit has had a profound impact on demand in the 'real' economy, once more much as occurred in 1929, and is critically affecting business solvency and employment, the severity of which remains unclear. The era of financialisation has also left a public confronting ever greater employment insecurity while being vastly more indebted than at any in history, placing increased risks and pressure on relationships and families.

10.6 The impact of the era of finance on housing markets has also produced huge inequities and social problems. The credit fuelled housing bubble has afforded large unearned profits for some while decent, secure housing is now out of reach of a substantial sector of the population, at least until the market inevitably corrects. This has led to larger numbers of people living with parents for much longer than has been customary in late modernity and, thus, postponing some of the normally anticipated life transitions that require the setting up of a home. Property investment and speculation has also entailed that many of the 'priced' out are now housed on highly insecure terms, in properties that they may have comfortably purchased without the activities of the finance, and government, supported activities of investors. High prices also entail that, in many cases, people cannot access homes in more attractive areas or near family, leading to geographical as well as social polarisation. It is perhaps time for us to redefine 'properties' as 'homes' once more and focus on their social rather than economic function.

10.7 The growing inequalities and insecurity of that have grown in the neo-liberal era have also had a profound impact on the public realm, generating anxiety, ill-health, resentment and conflict, both latent and real, that may erupt should the crisis prove to be as severe and protracted as many commentators now fear (Wilkinson, 2005).

10.8 As to the management of the economy, and the role and organisation of the financial sector within it, there are numerous powerful voices calling for a return to business as usual, albeit with taxpayers support. Perhaps, we might now conclude however, on the evidence of the current crisis and those that have gone before, that the financial sector, at least in its current form, offers a source of 'wealth creation' that we can no longer afford.

10.9 Perhaps, however, as suggested above, the most damaging legacy of this era is its deeper psychological, cultural and social impact. The exhortations of political leaders and the strident exemplars of success that have characterised this era have promoted a worldview where empathy, loyalty, commitment, honesty, trust and caring for others are considered signs of weakness; to be disparaged. Echoing the aforementioned credo embodied by the baleful fictional figure of Gordon Gekko, this is a psychology currently displayed in BBC's 'The Apprentice', and described in Geraint Anderson's 'City Boy', where human contact is reduced to cold, commercialised, competitive and calculative relations that can be cultivated, manipulated, exploited and severed for personal advantage, with little reflection (Anderson, 2008). To appropriate Richard Sennett's term, this 'corrosion of character' may take much longer to repair than the economic damage (Sennett, 1998).

\section{References}

ANDERSON, G. (2008) City Boy: Beer and Loathing in the Square Mile, Headline: London. 
ELLIOTT, L. \& Atkinson, D. (2008) The Gods That Failed, Bodley Head: London.

FORD J. (2008) The Money Monster: How Finance Grew Too Big, Prospect, November, 2008.

KRUGMAN, P (2008) The Return of Depression Economics and the Crisis of 2008 , Norton: New York

MCWHIRTER, I. (2007) 'Paying the social cost of high-price housing', The Herald $16^{\text {th }}$ July.

MEYER, P. (2009) American excess: A Wall Street trader tells all, The Independent, $27^{\text {th }}$ April

Michie, J. \& Sheehan, M. (2003) Labour market deregulation, 'flexibility' and innovation. Cambridge Journal of Economics, 27, 123-143.

GALBRAITH, J. K. (1961) The Great Crash of 1929, Penguin: Harmondsworth

ORHANGAZI, O. (2008) Financialization and the US Economy, Edward-Elgar: USA

RAPLEY, J. (2004) Globalization and Inequality: Neoliberalism's Downward Spiral , Lynne Rienner: Boulder, Co.

SENNETT, R (1998) The Corrosion of Character, Norton: New York.

SHILLER, R. (2000) Irrational Exuberance, Princeton University Press: New Jersey.

STIGLITZ, J (2003) The Roaring Nineties, Penguin: Harmondsworth.

WEBER (1930) The Protestant Ethic \& the Spirit of Capitalism, Allen \& Unwin: London.

WILKINSON, R. (2005) The Impact of Inequality: How to Make Sick Societies Healthier, Routledge:

London.

'In Come the Waves: The Global Housing Boom', The Economist, 16 ${ }^{\text {th }}$ June 2005.

EXTRACT FROM PRESIDENT FRANKLIN D. ROOSEVELTS INAUGURAL ADDRESS, Inaugural Addresses of the Presidents of the United States. Washington, D.C.: U.S. G.P.O.: for sale by the Supt. of Docs., U.S. G.P.O., 1989; Bartleby.com, 2001. <http://www.bartleby.com/br/124.html > (Accessed, 30th April 2009) 